\title{
Distribution and Abundance of Azotobacter in Wheat Fields of Bangladesh
}

\author{
Muhammad Ali Akond, Sanzida Mubassara and M Motiur Rahman* \\ Department of Botany, Jahangirnagar University, Savar, Dhaka 1342, Bangladesh
}

[Received 28 September 2006; Accepted 08 December 2007]

\begin{abstract}
The distribution and abundance of Azotobacter as well as heterotrophic bacteria in root, rhizosphere soil and non-rhizosphere soil samples from various wheat fields of four different areas under three districts were investigated in this study. The potential for nitrogen-fixation of five Azotobacter isolates was also detected. All samples tested were positive in their capacity to harbouring Azotobacter with a range of 26-100\%. The population of heterotrophic bacteria ranged from $2.1 \times 10^{7}$ to $1.2 \times 10^{8} \mathrm{cfu} / \mathrm{g}$ sample. Ranges of total number of Azotobacter in different samples were $5.2 \times 10^{4}$ to $7.2 \times 10^{4} \mathrm{cfu} / \mathrm{g}, 17.2 \times 10^{4}$ to $25.5 \times 10^{4} \mathrm{cfu} / \mathrm{g}$, and $12.4 \times 10^{4}$ to $16.7 \times 10^{4}$ cfu/g respectively for root, rhizosphere soil and non-rhizosphere soil. A positive correlation was found in Azotobacter colonization between root and rhizosphere, but it was negative in case of the population between heterotrophic bacteria and Azotobacter in rhizosphere. The highest amount of $\mathrm{N}$ was found to be fixed by the isolate $M_{1}$ and the lowest by the isolate $M_{4}$ and it was respectively 9.26 and $5.45 \mathrm{mg} \mathrm{N} / \mathrm{g}$ substrate. In terms of the capacity to fix nitrogen in laboratory condition the five isolates of Azotobacter could be arranged as $M_{1}>M_{3}>M_{5}>M_{4}>M_{2}$.
\end{abstract}

Keywords: Azotobacter, Wheat field, Nitrogen fixing potential

The study of important nitrogen-fixing bacteria is very essential with a view to finding efficient strains to develop biofertilizer for crops like wheat. Biological nitrogen fixation is important in nonleguminous crop, e.g., rice and wheat farming systems because it is an inexpensive source of nitrogen for higher yields. This process diminishes the need for expensive chemical fertilizers, which have been associated with numerous health and environmental problems. Biological nitrogen fixation in agriculture usually refers to nodule forming dicotyledonous leguminous plants. Monocotyledonous plants like rice and wheat lacking genes for nodulation must depend upon nitrogen from chemical fertilizers and various sources of biological nitrogen fixation in the ecosystem by free-living or associative organisms.

Azotobacter is a free-living nitrogen-fixing soil bacterium. This organism was first isolated and described by Beijerinck in $1901^{1}$. Besides nitrogen fixation, Azotobacter has been found to synthesize growth promoting substances and antibiotics ${ }^{2}$. By virtue of these attributes, Azotobacter can play nutritional and stimulatory roles and can benefit the plants with its manifold actions. Further, Azotobacter inoculation has been found to increase the growth and yield of a wide variety of cereals, pulses, vegetable crops, fruit crops and cash crops ${ }^{3}$. It is indeed interesting to note that Azotobacter is among the first organisms to develop in a newly formed soil, and the number of this organism in soil runs parallel with its fertility ${ }^{4}$ Though the occurrence and distribution of Azotobacter in the soils of different parts of the world have been well studied ${ }^{5}$, such occurrence and distribution in the soils of Bangladesh have so far received very little attention ${ }^{6}$. The present work therefore was undertaken to study the distribution and abundance of Azotobacter in some wheat field soils of Manikganj, Dhamrai, Gajipur and Savar, Bangladesh.

Samples of non-rhizosphere soil, rhizosphere soil and wheat plant were collected from ten various wheat fields of four different collection areas such as Manikganj, Dhamrai, Gajipur and Savar. Rhizosphere soil was collected from the rhizosphere region of the plants at the depth of $2-3 \mathrm{~cm}$ and non-rhizosphere soil was also collected from a nearby place of the field at the same depth. The soil $\mathrm{pH}$ was determined by an electric $\mathrm{pH}$ meter. For this purpose a suspension with a soil:water ratio of $1: 2.5(\mathrm{w} / \mathrm{v})$ of each collected sample was used. One gram of each soil and root sample was used for the purpose of isolation of Azotobacter. Roots were washed first with tap water and then with distilled water twice. The pieces of roots were taken in a sterile mortar and macerated with the help of a sterile pestle. Then $10 \mathrm{ml}$ of sterile distilled water was added to prepare a suspension of root sample. Suspension for soil sample was made using the serial dilution method. Plates of LG agar medium $^{7}$ were inoculated with the suspension of root and soil samples by streaking method. Plates were incubated at $30^{\circ} \mathrm{C}$ for 5 days. Development of flat, soft, milky and mucoid colonies was the indication for the growth of Azotobacter. For enumeration of Azotobacter suspension of both root and soil samples were prepared using serial dilution method and plated on LG agar medium. After incubation 5 days at $30^{\circ} \mathrm{C}$, the colonies appeared on the agar plates were counted. Nitrogen fixation was determined in terms of the quantity of nitrogen gained in 5-days-old culture of each isolate developed in $50 \mathrm{ml} \mathrm{LG}$ broth medium. Nitrogen in culture was estimated by micro-Kjeldahl method.

\footnotetext{
*Corresponding author:

M Motiur Rahman, Department of Botany, Jahangirnagar University, Savar, Dhaka 1342, Bangladesh

Cell: 01818 137949; E-mail: motiur_bot@yahoo.com
} 
Table 1 shows the $\mathrm{pH}$ values of different soil samples. All the soil samples were found to be slightly acidic to near the neutral ranging from 6.45 to 6.90 .

Table 1. $p H$ values of soil samples collected from different wheat fields

\begin{tabular}{lcc}
\hline $\begin{array}{l}\text { Collection } \\
\text { place }\end{array}$ & \multicolumn{2}{c}{$\mathrm{pH}$ value of soil sample } \\
\cline { 2 - 3 } & $\begin{array}{c}\text { Rhizosphere } \\
\text { soil }\end{array}$ & $\begin{array}{c}\text { Non-rhizosphere } \\
\text { soil }\end{array}$ \\
\hline $\mathrm{L}_{1}$ & 6.65 & 6.45 \\
$\mathrm{~L}_{2}$ & 6.80 & 6.65 \\
$\mathrm{~L}_{3}$ & 6.75 & 6.90 \\
$\mathrm{~L}_{4}$ & 6.60 & 6.55 \\
\hline $\mathrm{L}_{1}=$ Wheat fields of Manikganj; $\mathrm{L}_{2}=$ Wheat fields of dhamrai; $\mathrm{L}_{3}=$ Wheat \\
fields of Gajipur; $\mathrm{L}_{4}=$ Wheat fields of Savar.
\end{tabular}

Table 2 shows the occurrence of Azotobacter in different soil and root samples collected from various wheat fields of four different areas. The percentage of samples tested positive for Azotobacter ranged from $26-45 \%$ for root, $98-100 \%$ for rhizosphere soil and 84-99\% for non-rhizosphere soil. Usually Azotobacter does not prefer rhizoplane for colonization probably due to acidity of the concentrated root exudates of plants ${ }^{8}$. This study reflects also the findings of Shilpi et al. ${ }^{9}$. Azotobacter is widely distributed and a considerable number of surveys in all the continents have detected Azotobacter in 30-80\% soil samples.

Table 2. Occurrence of Azotobacter in different wheat fields of four collection areas

\begin{tabular}{lcccc}
\hline Sample type & \multicolumn{4}{c}{ \% positive sample } \\
\cline { 2 - 5 } & $\mathrm{L}_{1}$ & $\mathrm{~L}_{2}$ & $\mathrm{~L}_{3}$ & $\mathrm{~L}_{4}$ \\
\hline Wheat root & 45 & 38 & 32 & 26 \\
Rhizosphere soil & 99 & 100 & 98 & 100 \\
Non-rhizosphere soil & 87 & 97 & 99 & 84 \\
\hline
\end{tabular}

$\mathrm{L}_{1}=$ Wheat fields of Manikganj; $\mathrm{L}_{2}=$ Wheat fields of dhamrai; $\mathrm{L}_{3}=$ Wheat fields of Gajipur; $\mathrm{L}_{4}=$ Wheat fields of Savar.

Table 3 shows that rhizosphere soil harbours the nitrogen-fixing Azotobacter in higher numbers than the non-rhizosphere soil does. This finding is in agreement with the study of Bhat ${ }^{4}$, Kavimandan et al. ${ }^{10}$, Fuller and Hanks ${ }^{11}$, Subba Rao ${ }^{1}$ and Shilpi et al. ${ }^{9}$ though in 1988 Sattar and Solaiman ${ }^{12}$ reported higher Azotobacter population in non-rhizosphere soil compared to rhizosphere ones of rice fields. In general, the population of the organism ranged from $2.6 \times 10^{5}$ to $4.5 \times 10^{5} \mathrm{cfu} / \mathrm{g}, 1.7 \times 10^{5}$ to $2.5 \times 10^{5} \mathrm{cfu} / \mathrm{g}$ and $1.2 \times 10^{5}$ to $1.7 \times 10^{5} \mathrm{cfu} / \mathrm{g}$ of root samples, rhizosphere and non-rhizosphere soils respectively.

Azotobacter is rarely found in the soil more acidic than the $\mathrm{pH}$ value $6.0^{5}$. This investigation shows that the $\mathrm{pH}$ values within the range of 6.45-6.90 contains a considerable quantity of Azotobacter. The highest percentage for Azotobacter positive samples tested was $100 \%$ in case of rhizosphere soil and the lowest was found in wheat root samples and it was only $26 \%$. The percentage ranges of the samples tested positive were $26-45 \%$, 98-100\% and 84-99\% respectively for root, rhizosphere and nonrhizosphere soil. Shilpi et al. ${ }^{9}$ also reported almost similar result in case of rice field ecosystem.

Population of Azotobacter in various samples is presented in the Table 3. Azotobacter population was found to be the lowest in the rhizoplane and highest in the rhizosphere soil samples, which ranged respectively from $5.2 \times 10^{4}$ to $7.2 \times 10^{4} \mathrm{cfu} / \mathrm{g}$ and $17.2 \times 10^{4}$ to $2.5 \times 10^{5} \mathrm{cfu} / \mathrm{g}$ (Table 3). The average population size of the Azotobacter in case of non-rhizosphere soil is $1.5 \times 10^{5} \mathrm{cfu} / \mathrm{g}$. This study reflects much better finding of Azotobacter population than in the report made by Shilpi et $a l .{ }^{9}$, and was in agreement with the findings of Vancura et al. ${ }^{13}$, Abd-el-Malek ${ }^{14}$, Subba Rao ${ }^{1}$ and Rao and Venkateswarlu ${ }^{15}$.

The population of the heterotrophic bacteria was also determined in the studied samples (Table 4). The highest mean population size for heterotrophic bacteria (1.2 x $10^{8} \mathrm{cfu} / \mathrm{g}$ sample) was observed in rhizosphere soil samples and the lowest one was in case of root samples (2.1 x $10^{7} \mathrm{cfu} / \mathrm{g}$ sample). The population of heterotrophic bacteria in wheat root samples varied from $2.1 \times 10^{7}$ to $3.3 \times 10^{7} \mathrm{cfu} / \mathrm{g}$, and it ranged from $9.9 \times 10^{7} \mathrm{cfu} / \mathrm{g}$ to $1.2 \times 10^{8} \mathrm{cfu} / \mathrm{g}$ and from $3.2 \times 10^{7}$ to $4.3 \times 10^{7} \mathrm{cfu} / \mathrm{g}$ respectively in rhizosphere and non-rhizosphere soils which is slightly smaller than that of wheat reported by Khan et al. ${ }^{16}$. According to Alexander ${ }^{17}$, plate counts of heterotrophic bacteria ranges usually from several hundred to up to 200 million cfu/g dry soil.

Linear correlation analysis reveals that the population size of rhizospheric Azotobacter is positively correlated with that of root $(r=0.96, p=<0.1)$, i.e., higher number of Azotobacter in rhizosphere increases the probability of root colonization by it. But at the same time there was found a negative correlation $(r=-81)$ in between the colonization of heterotrophic bacteria and Azotobacter in wheat rhizosphere which reflects an adverse effect of heterotrophic bacteria on Azotobacter colonization in rhizosphere soils.

Table 3. Population of Azotobacter in various samples collected from different wheat fields of four collection areas

\begin{tabular}{lccccc}
\hline Sample type & \multicolumn{3}{c}{ Number of organism per gram sample } & \multirow{2}{*}{ Mean } \\
\cline { 2 - 5 } & $\mathrm{L}_{1}$ & $\mathrm{~L}_{2}$ & $\mathrm{~L}_{3}$ & $\mathrm{~L}_{4}$ & \\
\hline Wheat root & $6.8 \times 10^{4}$ & $5.5 \times 10^{4}$ & $5.2 \times 10^{4}$ & $7.2 \times 10^{4}$ & $6.2 \times 10^{4}$ \\
Rhizosphere soil & $2.5 \times 10^{5}$ & $1.7 \times 10^{5}$ & $2.0 \times 10^{5}$ & $1.8 \times 10^{5}$ & $2.0 \times 10^{5}$ \\
Non-rhizosphere soil & $1.7 \times 10^{5}$ & $1.5 \times 10^{5}$ & $1.5 \times 10^{5}$ & $1.2 \times 10^{5}$ & $1.5 \times 10^{5}$ \\
\hline
\end{tabular}

$\mathrm{L}_{1}=$ Wheat fields of Manikganj; $\mathrm{L}_{2}=$ Wheat fields of dhamrai; $\mathrm{L}_{3}=$ Wheat fields of Gajipur; $\mathrm{L}_{4}=$ Wheat fields of Savar. 
Table 4. Population of total heterotrophic bacteria in various samples collected from wheat fields of four collection sites

\begin{tabular}{lccccc}
\hline Sample type & \multicolumn{4}{c}{ Number of organism per gram sample $\left(\mathrm{x} 10^{6}\right)$} & \multirow{2}{*}{ Mean } \\
\cline { 2 - 5 } & $\mathrm{L}_{1}$ & $\mathrm{~L}_{2}$ & $\mathrm{~L}_{3}$ & $\mathrm{~L}_{4}$ & \\
\hline Wheat root & $3.3 \times 10^{7}$ & $2.5 \times 10^{7}$ & $2.1 \times 10^{7}$ & $2.8 \times 10^{7}$ & $2.7 \times 10^{7}$ \\
Rhizosphere soil & $1.2 \times 10^{8}$ & $1.2 \times 10^{8}$ & $9.9 \times 10^{7}$ & $1.1 \times 10^{8}$ & $1.1 \times 10^{8}$ \\
Non-rhizosphere soil & $4.3 \times 10^{7}$ & $3.2 \times 10^{7}$ & $3.6 \times 10^{7}$ & $4.0 \times 10^{7}$ & $3.8 \times 10^{7}$ \\
\hline
\end{tabular}

$\mathrm{L}_{1}=$ Wheat fields of Manikganj; $\mathrm{L}_{2}=$ Wheat fields of dhamrai; $\mathrm{L}_{3}=$ Wheat fields of Gajipur; $\mathrm{L}_{4}=$ Wheat fields of Savar.

Among various colonies grown on the LG agar plates five were selected based on their growth performances to be studied for their nitrogen fixing potential which might led to any effective application of this organism through studying other attributes in the near future. Information about five selected strains are given in the Table 5. Species of Azotobacter was first studied by Beijerinck ${ }^{17}$ showing the capacity to fix atmospheric nitrogen. The nitrogen fixing potential of the selected five strains of Azotobacter in this study was determined (Table 5).

Table 5. Nitrogen fixing potential of the selected Azotobacter isolates recover from wheat fields

\begin{tabular}{llcc}
\hline $\begin{array}{l}\text { Selected } \\
\text { isolate }\end{array}$ & Source & $\begin{array}{c}\text { Collection } \\
\text { place }\end{array}$ & $\begin{array}{c}\text { Nitrogen fixing } \\
\text { potential } \\
\text { (mg N/g substrate) }\end{array}$ \\
\hline $\mathrm{M}_{1}$ & Rhizosphere soil of wheat & $\mathrm{L}_{1}$ & 9.26 \\
$\mathrm{M}_{2}$ & Histosphere of wheat root & $\mathrm{L}_{3}$ & 5.72 \\
$\mathrm{M}_{3}$ & Rhizosphere soil of wheat & $\mathrm{L}_{4}$ & 7.52 \\
$\mathrm{M}_{4}$ & Non-rhizosphere soil & $\mathrm{L}_{2}$ & 5.45 \\
$\mathrm{M}_{5}$ & Histosphere of wheat root & $\mathrm{L}_{2}$ & 6.93
\end{tabular}

$\mathrm{L}_{1}=$ Wheat fields of Manikganj; $\mathrm{L}_{2}=$ Wheat fields of dhamrai; $\mathrm{L}_{3}=$ Wheat fields of Gajipur; $\mathrm{L}_{4}=$ Wheat fields of Savar.

It was found that the selected strains could fix nitrogen ranging from 5.45 to $9.26 \mathrm{mg} \mathrm{N} / \mathrm{g}$ substrate by 5-days-old $25 \mathrm{ml}$ culture. The strain $\mathrm{M}_{1}$ could fix the highest amount of nitrogen $(9.26 \mathrm{mg} \mathrm{N} / \mathrm{g}$ substrate) and the strain $\mathrm{M}_{4}$ fixed the least amount $(5.45 \mathrm{mg} \mathrm{N} / \mathrm{g}$ substrate). Shilpi et al. ${ }^{18}$ reported nitrogen fixation by Azotobacter within the range of $0.69-1.18 \mathrm{mg} \mathrm{N} / 25 \mathrm{ml}$ culture. According to Hamdi $^{19}$ the normal capacity range for nitrogen fixation by Azotobacter is $10 \mathrm{mg} \mathrm{N} / \mathrm{g}$ of carbohydrate consumed. Jensen ${ }^{20}$ reported a range of nitrogen fixation by Azotobacter was 10-15 mg $\mathrm{N} / \mathrm{g}$ of agar consumed. So, the present study shows that the isolates recovered from the wheat fields are of average standard in terms of their nitrogen fixing potential in the laboratory condition.

\section{References}

1. Subba Rao NS. 1982. Biofertilizers in Agriculture, pp 77-91. Oxford \& IBH Publishing Co Pvt Ltd, New Delhi.

2. Shende ST, Apte RG \& Singh T. 1975. Multiple action of Azotobacter. Ind J Genet Plant Breeding. 35: 314.

3. Bhandari SC \& Somani LL. 1990. Azotobacter. In Biofertilizers (Somani LL ed), pp 355-361. Scientific Publishers, Jodhpur.
4. Bhat JV. 1961. Bacterization experiment with Azotobacter. In Radioisotopes, Fertilizers and Cow Dung Gas Plant (Raghvan D, Kachroo P \& Doraiswami S eds), p 317. ICAR, New Delhi.

5. Thompson JP \& Skermann VBD. 1979. Azotobacteraceae: The Taxonomy and Ecology of the Aerobic Nitrogen-Fixing Bacteria. Academic Press, London.

6. Sattar MA. 1991. Rice based BNF research in Bangladesh: Problems and prospects. In Biological Nitrogen Fixation Associated with Rice Production (Dutta SK \& Charles S eds), pp 211-218. Oxford \& IBH Publishing Co Pvt Ltd, New Delhi.

7. Dobereiner J. 1980. Forage grasses and grain crops. In Methods for Evaluating Biological Nitrogen Fixation (Bergressen FJ ed), pp 535555. John Wiley \& Sons, New York.

8. Dobereiner J. 1974. Nitrogen fixing bacteria in the rhizosphere. In The Biology of Nitrogen Fixation (Quispel A ed), pp 86-120. North Holland, Amsterdam.

9. Shilpi RY, Akond MA \& Khan ZUM. 1993. Distribution and abundance of Azotobacter in the soils of Jahangirnagar University campus. Bangladesh J Life Sci. 5(1): 19-24.

10. Kavimandan SK, Lakshmi Kumari M \& Subba Rao NS. 1978. Nonsymbiotic nitrogen-fixing bacteria in the rhizosphere of wheat, maize and sorghum. Proc Indian Acad Sci. 87B: 299-302.

11. Fuller WH \& Hanks K. 1982. Distribution of Azotobacter in arid soils. Plant Soil. 64(3): 355-361.

12. Sattar MA \& Solaiman ARM. 1988. Distribution and abundance of Azotobacter spp in rice rhizosphere of some Bangladesh soils. Bangladesh J Sci Ind Res. 23(1-4): 201-203.

13. Vancura V, Abd-el-Malek Y \& Zayed MN. 1965. Azotobacter and Beijerinckia in the soils and rhizosphere of plants in Egypt. Folia Microbiol. 10: 224-229.

14. Abdel-el-Malek Y. 1971. Free-living nitrogen-fixing bacteria in Egyptian soils and their possible contribution to soil fertility. Plant Soil. Special Volume: 423-442.

15. Rao AV \& Venkateswarlu B. 1982. Occurrence of Azotobacter and nitrogen fixation in the desertic soils. Indian J Microbiol. 22(4): 255-257.

16. Khan ZUM, Akond MA \& Mubassara S. 2001. Population of heterotrophic bacteria and Azospirillum in wheat field soil and nitrogen-fixing potential of the same soil. Bangladesh J Life Sci. 13(1-2): 1-5.

17. Alexander M. 1977. Introduction to Soil Microbiology. Wiley Eastern Ltd, New Delhi.

18. Shilpi RY, Akond MA \& Khan ZUM. 1998. Growth and nitrogenfixing potential of Azotobacter isolated from the Jahangirnagar University campus. Bangladesh J Life Sci. 10(1-2): 1-5.

19. Hamdi YA. 1982. Application of nitrogen-fixing systems in soil improvement and management. FAO Soil Bull. 49: 45-82.

20. Jensen HL. 1953. Azotobacter as a crop inoculant. Proc Int Congr Microbiol Rome. 6: 245. 